\title{
Onion Extract Application Effects on Flowering Behavior and Yield, and a few Chemical Constituents of Shoots throughout Dormancy Break in "Anna" Apple Trees
}

\author{
Mohamed A. Seif El-Yazal ${ }^{1}$, Samir A. Seif El-Yazal' ${ }^{2}$, Mohamed E. Morsi², \\ Mostafa M. Rady 1
}

${ }^{1}$ Botany Department, Faculty of Agriculture, Fayoum University, Fayoum 63514, Egypt.

${ }^{2}$ Horticulture Department, Faculty of Agriculture, Fayoum University, Fayoum 63514, Egypt.

E-mail address: mas04@fayoum.edu.eg

Keywords: Apple (Malus sylvestris, Mill), dormancy, onion extract, bud break, flowering, yield, chemical constituents.

\begin{abstract}
Metabolic changes in water content, total carbohydrates, total sugars, reducing sugars, anthocyanin, total free amino acids, proline and total indoles in shoots of "Anna" apple (Malus sylvestris, Mill) trees were investigated during dormancy and bud break under the effect of foliar application of four onion extract rates $(5,10,15$ and $20 \%)$. Flowering percentage and fruit yield characteristics (i.e., fruit-set, number of fruits tree ${ }^{-1}$ and fruit yield tree ${ }^{-1}$ ) were increased, while number of days recorded to reach full bloom were reduced with the application of both onion extract rates (15 or 20\%). In addition, contents of total carbohydrates, total sugars, reducing sugars, anthocyanin, total free amino acids, proline and total indoles in shoots were significantly increased in floral buds, particularly during bud break. In contrast, the content of free phenols was reduced. The best results were obtained from the rate of onion extract at the level of $20 \%$ followed by $15 \%$ that could be recommended for early and high percentage of flowering and increased yield by regulating the metabolism of amino acids, including proline and indoles in apple floral buds.
\end{abstract}

\section{Introduction}

Bud dormancy in woody perennials may be a sophisticated process that allows plants to survive long periods of adverse conditions, further more because the extremes of drought, cold, and heat [1]. Dormancy well studied in seeds, tubers, corms, and deciduous trees. However, the literature is scanty in evergreen tree species, wherever the dormancy discovered throughout winter months, a development known as winter dormancy ${ }^{2}$. Bud break is high $(>50 \%)$ once winters are cool but can drop below $20 \%$ in warm-temperate regions, with flower numbers below the economic level for crop production ${ }^{3}$. This varies can modification according per the year and conjointly the area of production. In late summer, declining photoperiods and temperatures cause shoot extension growth to prevent and conjointly the initiation of apical buds to protect the apical meristem $^{4}$. A specific signal (environmental or endogenous) perceived among the bud, induces and maintains these buds in a very state of endo-dormancy ${ }^{5,6}$. In temperate perennial species a amount of low temperatures (commonly noted as winter chilling), is needed to unleash buds from endodormancy. Heat winters in several countries usually limit the productivity of temperate fruit crops $7-10$.

Many investigations are conducted to by artificial means that interrupt dormancy in areas lacking spare chilling units with some chemicals [11-14]. Among such product, hydrogen cyanamide (Dormex) has been the foremost effective bud breaking agent for field use ${ }^{7}$. It's very effective and finally ends up in early and vigorous vegetative growth. Despite these attributes, hydrogen cyanamide is not accepted by organic protocols for apple production. The increasingly demand for organic manufacture, equally as premium prices (although premium costs don't basically interprets into higher profits) for organically big fruits, has driven farmers be convert a sizeable amount of farmland from ancient agricultural practices to the assembly of organic foods. Thus, it is necessary 
to hunt out environmentally friendly and operator safer budbreak promoters that unit measurement as H. cyanamide, acceptable for organic apple production. Seeking for novel alternatives to push early bud break, it is been incontestable that onion extract applied to grapevine and apple directly pruning was further economical [11], [15-17]. Similar satisfactory results were to boot obtained by victimization natural extracts like garlic extract ${ }^{18}$, inexperienced alga extract [19] and garlic extract [18]' The useful effects of onion extract on bud break, flowering, yield and some chemical constituents of varied fruit species were studied by several workers on some fruit trees [11], [15-17]. Consequently, this work was planned to review the results of exogenous application of onion extract at utterly totally different rates on bud break, flowering, and yield, equally as some chemical constituents of apple trees throughout utterly totally different stages of dormancy and dormancy unharness.

\section{Materials and Methods}

This experiment was allotted throughout the 2016 and 2017 seasons at intervals the plantation of the Horticulture Station in Aboksah, Abshwai, Fayoum Governorate, Egypt in an endeavor to interrupt of "Anna" apple variety (Malus sylvestris, Mill) budded on Malling-Merton 106 (MM 106) rootstock. The trees were 5 years previous once the experiment started and grown in loamy sand soil. Trees were designated in November 2015 a uniform as possible for spray treatments.

Onion extract (cv. Giza 20) was applied in five concentrations $0.0 \%$ (water), 5\%, 10\%, 15\% and $20 \%$ in water using onion extract. Each tree received $4 \mathrm{~L}$ of the assigned solution. Onion extracts were sprayed at two equal doses, the first was sprayed before the end of dormancy (nearly $20^{\text {th }}$ of December), and the second was applied one week later with a volume of $4 \mathrm{~L} \mathrm{tree^{-1 }}$ for each one in both seasons.

Each treatment was replicated on four individual (tree) and receiving only one of the following treatments:

1-Control

2- Onion extract at a level of 5\%

3 -Onion extract at a level of $10 \%$

4- Onion extract at a level of $15 \%$

5- Onion extract at a level of $20 \%$.

\section{Preparation of onion extracts}

Onion samples were ground victimization mortar and pestle and also the active ingredients were extracted by ethyl alcohol (95\%). The onion grain alcohol mixture was filtered and also the alcohol was removed by evaporating beneath vacuum $\left(30 \mathrm{C}^{\circ}\right)$ employing a rotary evaporator, Buchi model 011 . The extract was unbroken cool in icebox $\left(4 C^{\circ}\right)$ till use. Onion extract was diluted by water to convey the ultimate concentration needed $(5,10,15$ and $20 \%)$ directly before use.

A wetter super film at $0.1 \%$ was accessorial to the spraying answer. The trees were sprayed employing a back gum sprayer to the spur surface till well wetted. All the agricultural and farming practices were distributed as was common.

The following parameters were determined to evaluate the effect of different spray treatments of onion extract on bud-opining, flowering, yield, and chemical compositions of apple trees.

\section{Morphological characteristics}

In each the two consecutive seasons, bud counts were created for every tree. The dates on that flower and vegetative bud began to open were recorded. A number of vegetative and flower buds was counted once all buds were opened and therefore the percentages were calculated. The dormant buds were conjointly counted and were expressed as a proportion of the whole number of buds. The dates at that flowering reached 25,50,75 and 100 percent of the whole flowers were calculable in every treatment. Flowers whose scroll began to extend were tagged so as to estimate the percent of 
fruit set. The yield of fruits in $\mathrm{kg}$ tree ${ }^{-1}$, moreover as a number of mature fruits per tree, was recorded once fruits reached the industrial color to be picked.

\section{Chemical analysis}

Samples of one-year-old shoots, $\sim 1 \mathrm{~m}$ long, were collected from each replicates 9 day's intervals after spraying till March 3 in the two studied years for determination the seasonal changes in shoots components. Samples of one-year-old shoots were taken at haphazardly and straight off transported to the laboratory for the subsequent determination.

\section{Total carbohydrate determination in apple shoots}

Total carbohydrate was extracted from apple shoots by placed ten mg dry sample with 10 mil of $\mathrm{H}_{2} \mathrm{SO}_{4}(0.1 \mathrm{~N})$ during a tube and extracted on a boiling water bath for half-hour. The sample was filtered to get rid of the insoluble material. When filtering, the solution was completed to hundred mil with distilled water.

Carbohydrate contents were determined by phenol-sulfuric acid methodology [24]. Briefly, to one mil of sugar resolution, fifty $\mu 180 \%$ phenol and so three mil $98 \%$ sulfuric acid was added. The mixture vortexes were unbroken at room temperature for $30 \mathrm{~min}$ and thereafter the absorbance scan at $490 \mathrm{~nm}$.

\section{Total and reducing sugars determination}

Total and reducing sugars were determined as $\mathrm{mg} / \mathrm{g}$ recent weight exploitation phosphomolybdic acid chemical agent [25]. Briefly, sample $(500 \mathrm{mg})$ of frozen shoots was crushed in a very ceramic ware mortar and extracted with $50 \mathrm{ml}$ of $80 \%(\mathrm{v} / \mathrm{v})$ boiling ethanol alcohol for five min. The sample was filtered to get rid of the insoluble material. The extract was centrifuged at $10,000 \mathrm{rpm}$ for ten min. Then the quantity of the supernatant was adjusted to one hundred ml with water. Protein was precipitated by adding one $\mathrm{mL}$ of ethanol alcohol extract with three $\mathrm{ml}$ of basic lead acetate $\left(137 \mathrm{~g} \mathrm{~L}^{-1}\right)$ and therefore the excess lead acetate was precipitated with a solution of $1 \mathrm{M}$ sodium phosphate monobasic $\left(141.7 \mathrm{~g} \mathrm{~L}^{-1}\right)$. The mixture was centrifuged and also the volume of the supernatant was completed to ten milliliter. For determinant reducing sugars one $\mathrm{ml}$ of the filtrate was mixed with one $\mathrm{ml}$ of copper sulphate solution $(13.2 \mathrm{~g}$ sodium sulphate and $6.0 \mathrm{~g}$ copper sulphate were dissolved in one liter) and one $\mathrm{ml}$ of alkaline tartrate solution (12 $\mathrm{g}$ sodium potassium tartrate, $20 \mathrm{~g}$ anhydrous sodium carbonate, $20 \mathrm{~g}$ sodium bicarbonate and $18 \mathrm{~g}$ potassium oxalate were dissolved in one liter), then the mixture was heated in boiling water bathtub for ten minutes. When cooling, two $\mathrm{ml}$ of phosphomolybdic acid reagent $(23 \mathrm{~g}$ molybdic acid and five $\mathrm{g}$ sodium tungstate were dissolved in $200 \mathrm{ml}$ of $10 \%$ sodium hydroxide and boiled for $20-30 \mathrm{~min}$. When cooling $125 \mathrm{ml}$ of phosphoric acid were value-added and also the volume was completed to $500 \mathrm{ml}$ with water) was added and the developed blue color was measured at $540 \mathrm{~nm}$. For determinant total sugars, one $\mathrm{ml}$ of the filtrate was mixed with one $\mathrm{ml} 1 \mathrm{~N} \mathrm{HCl}$ then the mixture was neutralized with sodium bicarbonate solution $(1 \mathrm{~N})$, then the volume was completed to five milliliter. The total sugars were determined employing acknowledged volume $(1 \mathrm{ml})$, as delineate within the methodology of reducing sugars determination.

\section{Total anthocyanins determination in apple shoots}

Total anthocyanin content was analyzed [26] with some modifications. The apple shoots were extracted with $1 \% \mathrm{HCl}-\mathrm{MeOH}$ for twenty-four h at room temperature, in darkness with occasional shaking. The extracts were rigorously decanted and their absorbance was measured at 530 and 657 $\mathrm{nm}$. The formula A530 - 0.25A657 was wont to make amends for the absorption of chlorophyll degradation products [26]. Anthocyanin content was expressed as $\mathrm{mg}$ of cyaniding 3-glucoside in $100 \mathrm{~g}$ of dry matter, using 29,600 as molecular extinction constant.

\section{Total free amino acids determination in apple shoots}

Total free amino acids were determined by reaction with ninhydrin victimisation glycine as normal [27], [28] with some modification. Briefly, sample $(500 \mathrm{mg})$ of frozen shoots was extracted 
with fifty $\mathrm{ml}$ of $80 \%(\mathrm{v} / \mathrm{v})$ ethanol. The sample was filtered to get rid of the insoluble material. During a $25-\mathrm{mL}$ volumetrical flask, $1.0 \mathrm{~mL}$ of ethanol extract was added. This was followed by addition of $0.5 \mathrm{~mL}$ of $1 / 15 \mathrm{~mol} \mathrm{~L}^{-1}$ phosphate buffer solution $(\mathrm{pH} 8.04$ ) and $0.5 \mathrm{~mL}$ of $2 \%$ ninhydrin solution containing $0.8 \mathrm{mg} \mathrm{mL}^{-1}$ of $\mathrm{SnCl}_{2} \cdot 2 \mathrm{H}_{2} \mathrm{O}$. Mixtures within the volumetrical flasks were then placed during a boiling water bath for fifteen min. The probes were quickly cooled with cold water, and adjusted to $25 \mathrm{~mL}$ with water. Once they were left to face still for ten min, the absorbance values of these blue-purple products were measured against a reagent blank at $550 \mathrm{~nm}$.

\section{Free proline determination in apple shoots}

Free proline was decided [29]. Briefly, sample $(200 \mathrm{mg})$ of frozen shoots was extracted with five $\mathrm{ml}$ of $40 \%(\mathrm{v} / \mathrm{v})$ methanol alcohol heated to eighty ${ }^{\circ} \mathrm{C}$ for thirty min in hermetically sealed tubes. The supernatant (one $\mathrm{ml}$ ) was mixed in an exceedingly reaction tubing with two $\mathrm{ml}$ glacial acetic acid, one $\mathrm{ml}$ ninhydrin resolution $\left(25 \mathrm{mg} \mathrm{ml}^{-1}\right)$ and two $\mathrm{ml}$ of a mixture consisting of twenty fourth $(\mathrm{v} / \mathrm{v})$ distilled water, sixteenth $(\mathrm{v} / \mathrm{v})$ glacial acetic acid and sixteenth $(\mathrm{v} / \mathrm{v})$ orthophosphoric acid. The tubes were closed and heated for thirty min in an exceedingly water bath set to one handred ${ }^{\circ} \mathrm{C}$. The sample was cooled on ice, then three $\mathrm{ml}$ of toluene was added and therefore the mixture was jolted smartly. The colored toluene phase (upper phase) was saved and dehydrated with anhydrous $\mathrm{Na}_{2} \mathrm{SO}_{4}$. The extracts were unbroken within the dark for a minimum of two $\mathrm{h}$ before their absorbance was measured at $528 \mathrm{~nm}$. Proline concentration of the fresh shoot was calculated supported typical activity curve with concentrations starting from 0 to $0.025 \mathrm{mg} \mathrm{ml}^{-1}$.

\section{Extraction and determination of total indoles in apple shoots}

Total indoles was extracted from apple shoots by grinding two gram fresh shoots with fifty mil toluene and five mil 5\% TCA for one min. The purée was centrifuged for thirty min at 3500 rpm $(2534 \times \mathrm{g})$ to separate the toluene from the apple pulp. The resolvent layer was decanted and filtered through a $0.45 \mu \mathrm{m}$ syringe filter through a beaker containing anhydrous $\mathrm{Na}_{2} \mathrm{SO}_{4}$ (Aldrich).

Total indols in shoots were determined as $\mu \mathrm{g} \mathrm{g}^{-1}$ fresh weight [30] with some modification. The derivatizing chemical agent employed in the colorimetric method consisted of $1.25 \mathrm{~g}$ (4dimethyl-amino-benzaldehyde (DMAB)) in one handred $\mathrm{mL} \mathrm{MeOH}$ and $25.6 \mathrm{~mL}$ targeted $\mathrm{HCl}$ [31]. Within the procedure, $4 \mathrm{~mL}$ apple extract was diluted to ten $\mathrm{mL}$ with toluene, once that a two $\mathrm{mL}$ was vortexed for fifteen min with two $\mathrm{mL}$ derivatizing chemical agent. The ensuing mixture was centrifuged for six min at $3500 \mathrm{rpm}$ to separate the $\mathrm{MeOH}$ and toluene resolvent layers. The absorbance of the $\mathrm{MeOH}$ (bottom) layer was measured with a spectrophotometer at $567 \mathrm{~nm}$.

\section{Free phenolics determination in apple shoots}

Free phenols in shoots were determined as $\mathrm{mg}$ per $\mathrm{g}$ fresh weight victimisation FolinCiocalteu chemical agent and sodium carbonate solution [32], with some modification. Weight a random sample of 20-30 shoots as a representative of the fabric. Dry the shoots at $64-65{ }^{\circ} \mathrm{C}$ for sixteen hours. Grind every sample to a really fine powder. To extract free phenols, weigh hundred $\mathrm{mg}$ of powder in Associate in Nursing Eppendorf tube. Add $6.5 \mathrm{ml}$ of methyl alcohol (50\%). Shut the tubes, guaranteeing no evaporation can happen throughout extraction. Vortex completely the samples and place them in an exceedingly thermomixer at sixty five ${ }^{\circ} \mathrm{C}$ and 900 rev for half-hour. Take the tubes out of the thermomixer and allow them cool at room temperature. Centrifuge the tubes at $14,000 \mathrm{rev}$ for five minutes. Make sure that the supernatant does not have sample particles floating in it; if it will, centrifuge once more. Make the colorimetric reaction.

To determine free phenols content, $1 \mathrm{~mL}$ of supernatant was carefully transferred to a test tube. Add $0.8 \mathrm{~mL}$ of $25 \%$ Folin-Ciocalteu reagent (dissolve $10 \mathrm{~g}$ sodium tungstate and $2.5 \mathrm{~g}$ sodium molybdate in $70 \mathrm{ml}$ water. Add $5 \mathrm{ml} \mathrm{85 \%}$ phosphoric acid and $10 \mathrm{ml}$ concentrated hydrochloric acid. Reflux for $10 \mathrm{hr}$. Add $15 \mathrm{~g}$ lithium sulfate, $5 \mathrm{ml}$ water, and 1 drop bromine. Reflux for $15 \mathrm{~min}$. Cool to room temperature and bring to $100 \mathrm{ml}$ with water. Then take $2.5 \mathrm{ml}$ of F-C $2 \mathrm{~N}$ with $7.5 \mathrm{ml}$ of deionized water and vortex thoroughly). The F-C reagent should be added before the alkali to avoid the air-oxidation of phenolics. Add $2.2 \mathrm{~mL}$ of $400 \mathrm{mM} \mathrm{Na} \mathrm{CO}_{3}\left(4.25 \mathrm{~g}\right.$ of $\mathrm{Na}_{2} \mathrm{CO}_{3}(99.9 \%)$ in 
$100 \mathrm{ml}$ of deionized water). Cover the tubes with adhesive aluminum tape to avoid dropping off samples. Vortex the tubes at $800 \mathrm{rpm}$ for $10 \mathrm{~s}$. Incubate tubes at $42{ }^{\circ} \mathrm{C}$ for $9 \mathrm{~min}$ for color development. Take the tubes out of the oven and let them cool at room temperature, protect them from direct light. Read absorbance at $765 \mathrm{~nm}$ in a spectrophotometer.

\section{Statistical analysis}

The values of the determined characters were subjected to applied mathematics analysis per the quality procedure [33]. The ' $F$ ' test was applied to assess the significance of the treatment at fifth level of probability.

\section{Results}

\section{Date of flower bud opining}

Results bestowed in Table 1 clearly indicated that spraying apple trees with all the concentration hastened the start of flower bud break as comparison to the control. This earliness reached about eighteen and nineteen days for onion extract at $5 \%$, twenty and twenty days for onion extract at $10 \%$, twenty four and twenty five days for onion extract at $15 \%$, twenty six and twenty five for onion extract at $20 \%$, over the control in both seasons, severally.

Table 1. Effect of foliar spray with completely different onion extracts on flowering (\%) and flowering period (day) in "Anna" apple trees

\begin{tabular}{|c|c|c|c|c|c|c|c|c|}
\hline \multirow{3}{*}{$\begin{array}{l}\text { Treatments } \\
\text { (Extract level) }\end{array}$} & \multicolumn{8}{|c|}{ Date of flower bud opening } \\
\hline & \multicolumn{2}{|c|}{ Flowering start } & \multicolumn{2}{|c|}{$50 \%$ flowering } & \multicolumn{2}{|c|}{ Flowering end } & \multicolumn{2}{|c|}{ Duration } \\
\hline & 2016 & 2017 & 2016 & 2017 & 2016 & 2017 & 2016 & 2017 \\
\hline Control $(0 \%)$ & $13 \mathrm{Mar}$ & $13 \mathrm{Mar}$ & 2 April & 3 April & 7 April & 9 April & 25 & 27 \\
\hline $5 \%$ & $22 \mathrm{Feb}$ & $23 \mathrm{Feb}$ & 7 Mar & 8 Mar & $19 \mathrm{Mar}$ & 20 Mar & 25 & 25 \\
\hline $10 \%$ & $21 \mathrm{Feb}$ & $21 \mathrm{Feb}$ & 4 Mar & 6 Mar & $15 \mathrm{Mar}$ & 17 Mar & 22 & 24 \\
\hline $15 \%$ & $17 \mathrm{Feb}$ & $16 \mathrm{Feb}$ & 4 Mar & 5 Mar & $11 \mathrm{Mar}$ & 12 Mar & 22 & 24 \\
\hline $20 \%$ & $15 \mathrm{Feb}$ & $16 \mathrm{Feb}$ & $26 \mathrm{Feb}$ & $28 \mathrm{Feb}$ & 8 Mar & 9 Mar & 21 & 21 \\
\hline
\end{tabular}

As regards to the impact of the tested concentrations on fiftieth bud break, the present results clearly show that everybody treatments hastened fiftieth bud break as compared to the management. This timing reached regarding twenty six and twenty six days for onion extract at $5 \%$, twenty nine and twenty eight days for onion extract at $10 \%$, twenty nine and twenty nine days for onion extract at $15 \%$ and thirty five and thirty four days for onion extract at $20 \%$, over the control in both seasons, severally.

\section{Percentage of bud break}

Knowledge given in Table 2 clearly show that everyone concentrations gave a high share of flower bud-break as compared with the management. The most will increases were recorded with onion extract at twentieth, that recorded 11.20 and $9.10 \%$ in the course of each seasons over the management, severally.

Table 2. Effect of foliar spray with completely different onion extracts on the proportion of bud break and fruit setting in "Anna" apple trees

\begin{tabular}{llllll}
\hline \multirow{2}{*}{$\begin{array}{l}\text { Treatments (Extract } \\
\text { level) }\end{array}$} & \multicolumn{2}{l}{ Bud break (\%) } & & Fruit-set (\%) \\
\cline { 2 - 3 } \cline { 5 - 6 } $\mathbf{2 0 1 6}$ & $\mathbf{2 0 1 7}$ & & $\mathbf{2 0 1 6}$ & $\mathbf{2 0 1 7}$ \\
\hline Control (0\%) & $78.2 \mathrm{~b}$ & $79.3 \mathrm{c}$ & & $16.3 \mathrm{c}$ & $15.0 \mathrm{c}$ \\
$5 \%$ & $80.1 \mathrm{~b}$ & $80.8 \mathrm{bc}$ & & $17.4 \mathrm{bc}$ & $15.9 \mathrm{c}$ \\
$10 \%$ & $84.6 \mathrm{ab}$ & $82.7 \mathrm{abc}$ & & $18.1 \mathrm{~b}$ & $17.6 \mathrm{~b}$ \\
$15 \%$ & $88.0 \mathrm{a}$ & $87.4 \mathrm{ab}$ & & $20.0 \mathrm{a}$ & $19.7 \mathrm{a}$ \\
$20 \%$ & $89.4 \mathrm{a}$ & $88.4 \mathrm{a}$ & & $20.9 \mathrm{a}$ & $21.0 \mathrm{a}$ \\
\hline
\end{tabular}

Mean pairs followed by different letters are significantly different $(\mathrm{p}=0.05)$ by Duncan's test; $\mathrm{n}=6$ 


\section{Yields and its components}

Results in Tables $2 \& 3$ indicated that all the tested concentrations inflated apple yield and its elements (fruit-setting and fruit number) as compared to the management trees. Such trend was true throughout the two studied seasons. The utmost will increases were recorded with onion extract at twentieth, that recorded 28.49 and $40.16 \%$ for fruit-setting, 12.25 and $19.39 \%$ for fruit number and 30.50 and $24.01 \%$ for apple yield/tree among the two seasons, severally over the control trees.

Table 3. Effect of foliar spray with different onion extracts on number of fruit per tree and total yield per tree of "Anna" apple trees

\begin{tabular}{llllll}
\hline $\begin{array}{l}\text { Treatments } \\
\text { (Extract level) }\end{array}$ & \multicolumn{2}{l}{ Number of fruit tree } & & \multicolumn{2}{c}{ Total yield tree $^{-1}(\mathrm{~kg})$} \\
\cline { 2 - 3 } \cline { 5 - 6 } & $\mathbf{2 0 1 6}$ & $\mathbf{2 0 1 7}$ & & $\mathbf{2 0 1 6}$ & $\mathbf{2 0 1 7}$ \\
\hline Control (0\%) & $148.8 \mathrm{~b}$ & $148.8 \mathrm{c}$ & & $15.0 \mathrm{~d}$ & $15.5 \mathrm{c}$ \\
$5 \%$ & $149.2 \mathrm{~b}$ & $148.6 \mathrm{c}$ & & $16.5 \mathrm{c}$ & $15.6 \mathrm{c}$ \\
$10 \%$ & $153.3 \mathrm{~b}$ & $154.6 \mathrm{bc}$ & & $17.8 \mathrm{~b}$ & $16.7 \mathrm{bc}$ \\
$15 \%$ & $160.9 \mathrm{ab}$ & $164.8 \mathrm{ab}$ & & $19.5 \mathrm{a}$ & $17.2 \mathrm{~b}$ \\
$20 \%$ & $167.0 \mathrm{a}$ & $168.2 \mathrm{a}$ & & $19.6 \mathrm{a}$ & $19.2 \mathrm{a}$ \\
\hline
\end{tabular}

Mean pairs followed by different letters are significantly different $(\mathrm{p}=0.05)$ by Duncan's test; $\mathrm{n}=6$

\section{Shoot water content}

Shoots of "Anna" apple trees sprayed with onion extract at the rates of five, ten, fifteen and twentieth had exaggerated water contents in comparison to the management (Fig. 1). The water contents obtained with onion extract treatment at rate twentieth were surpassed their contents found with all others in most of the sampled dates. The most contents were obtained within the thirteen Feb and twenty two Feb samples, severally with the appliance, onion extract at the speed of $20 \%$ whereas their minimum contents were obtained within the eight Jan and seventeen Jan samples with water treatments, severally.

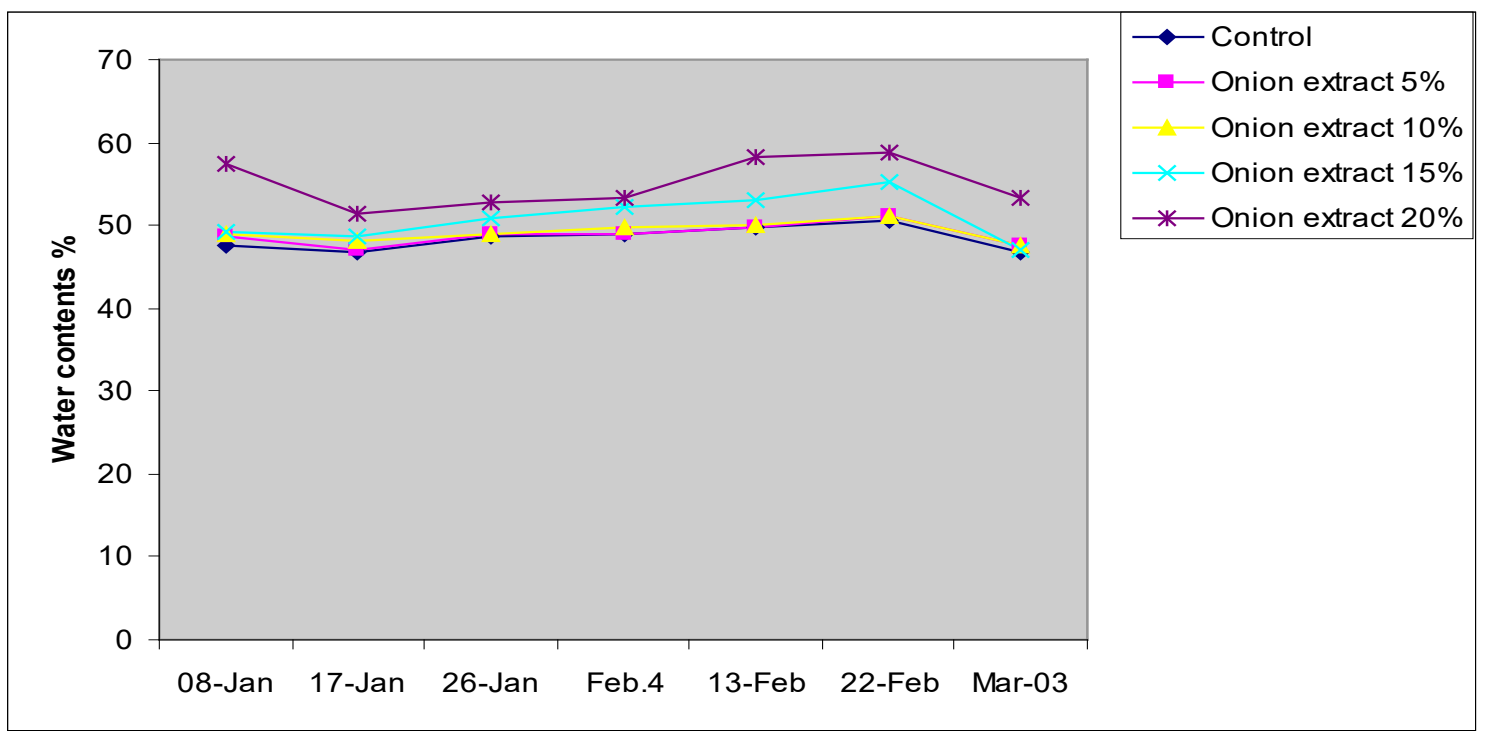

Fig. 1. Effect of foliar spray with different onion extracts on shoot water content of "Anna" apple trees

\section{Chemical constituents of shoots}

\section{Carbohydrates content}

In the time during which no vital variations were noticed between any of the four concentrations of onion extracts for carbohydrates in all sampled dates, onion extract at $20 \%$ 
considerably exaggerated total carbohydrates, total sugars and reducing sugars in comparison to the control (Figs. 2-4). It hiccoughed the control for total carbohydrates by $5.7 \%$, total sugars by $19.5 \%$ and reducing sugars by $16.0 \%$ for the sampled dates of twenty-two February, twentytwo February and three March severally. Additionally, data unconcealed that onion extract at 5\% was less effective during this regard.

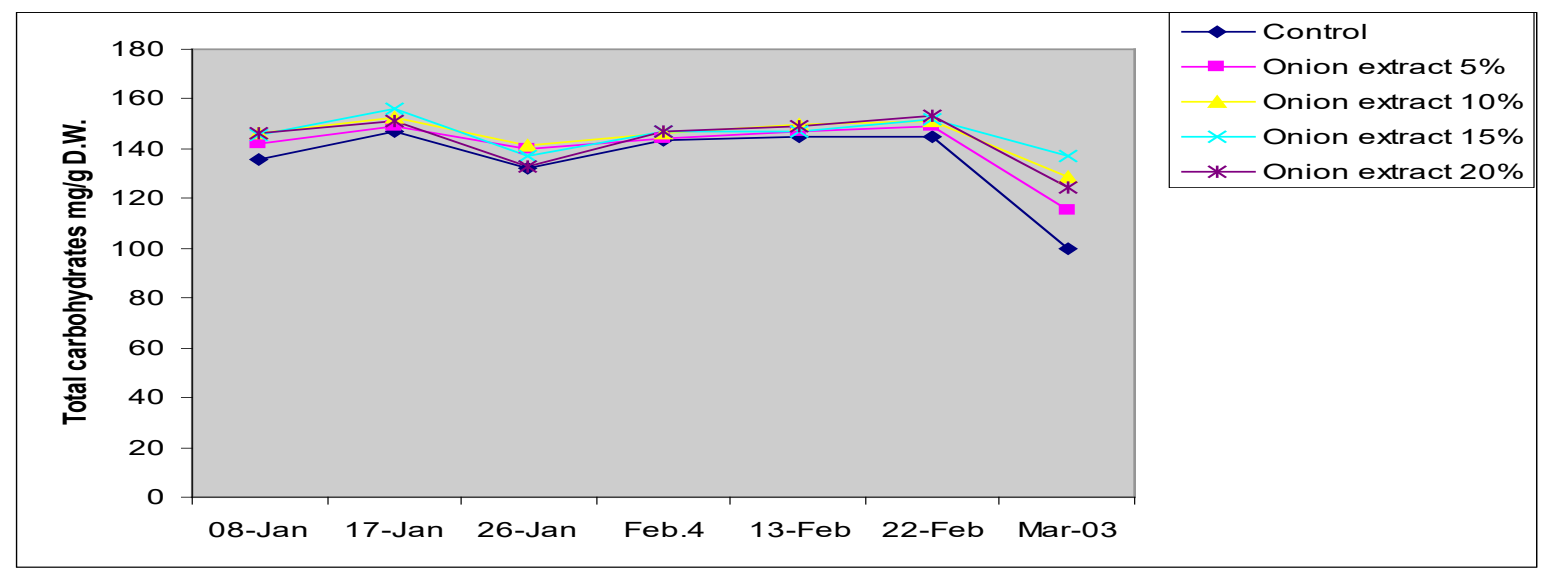

Fig. 2. Effect of foliar spray with different onion extracts on shoot total carbohydrates of "Anna" apple trees

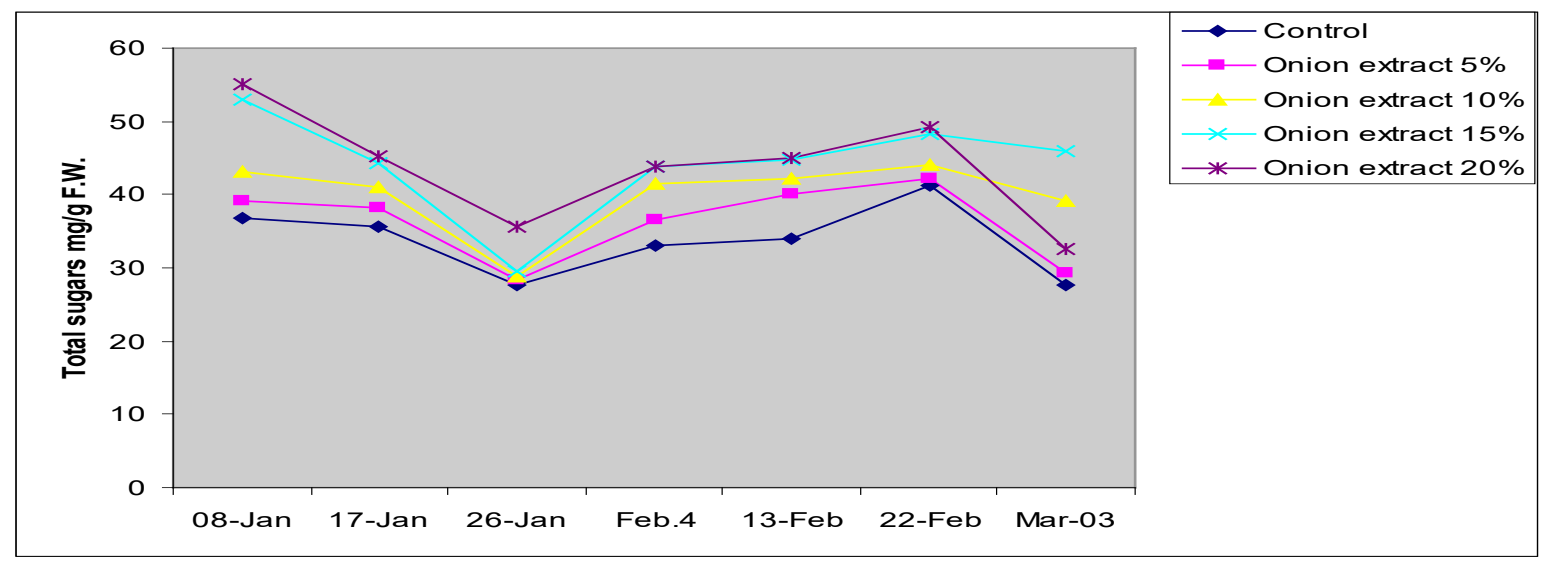

Fig. 3. Effect of foliar spray with different onion extracts on shoot total sugars of "Anna" apple trees

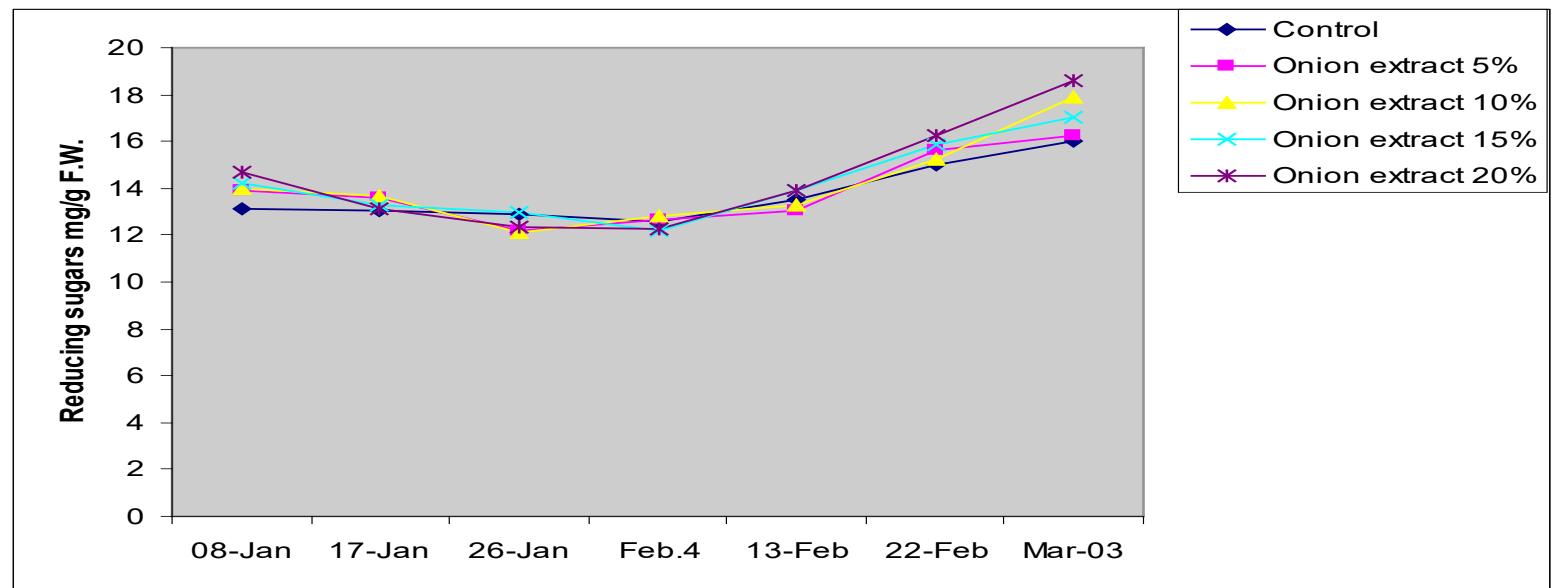

Fig. 4. Effect of foliar spray with different onion extracts on shoot reducing sugars of "Anna" apple trees 


\section{Anthocyanins content}

The data in (Fig. 5) indicated that everyone treatments exaggerated the amount of anthocyanine in shoots of "Anna" apple variety. The most effective data were obtained by spraying the trees with onion extract at the rate of $20 \%$. The rise was $36.3 \%$ for the sampled date of thirteen Feb over the control trees.

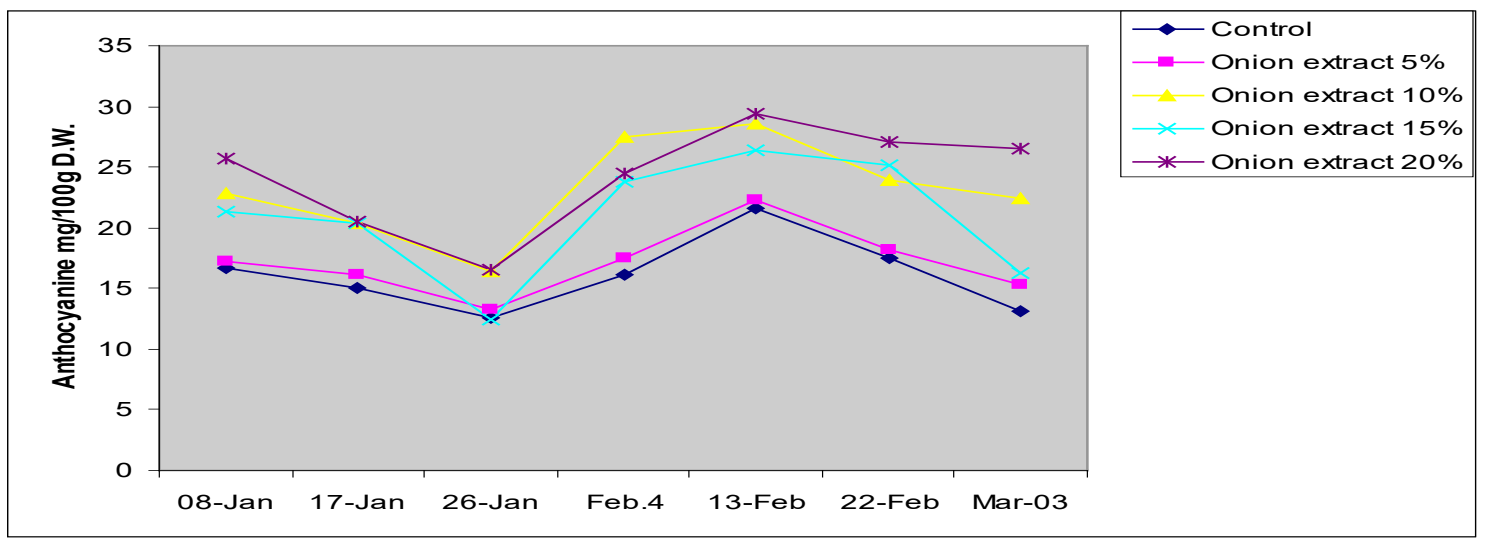

Fig. 5. Effect of foliar spray with different onion extracts on shoot anthocyanine of "Anna" apple trees

\section{Total free amino acids content}

Data bestowed in (Fig. 6) typically show that total free amino acids content in "Anna" apple variety bit by bit attenuated from the primary sample until twenty sixth January, thenceforth it inflated bit by bit reaching its most values at twenty second February, then attenuated towards the last sample(3th March). Regarding the effect of the spray treatments on total free amino acids, all treatments gave higher values of total free amino acids if compared to the control trees. The simplest results were obtained by spraying the trees by onion extract at the rate of $20 \%$. The rise was $19.2 \%$ for the sampled date of twenty second February, over the control trees.

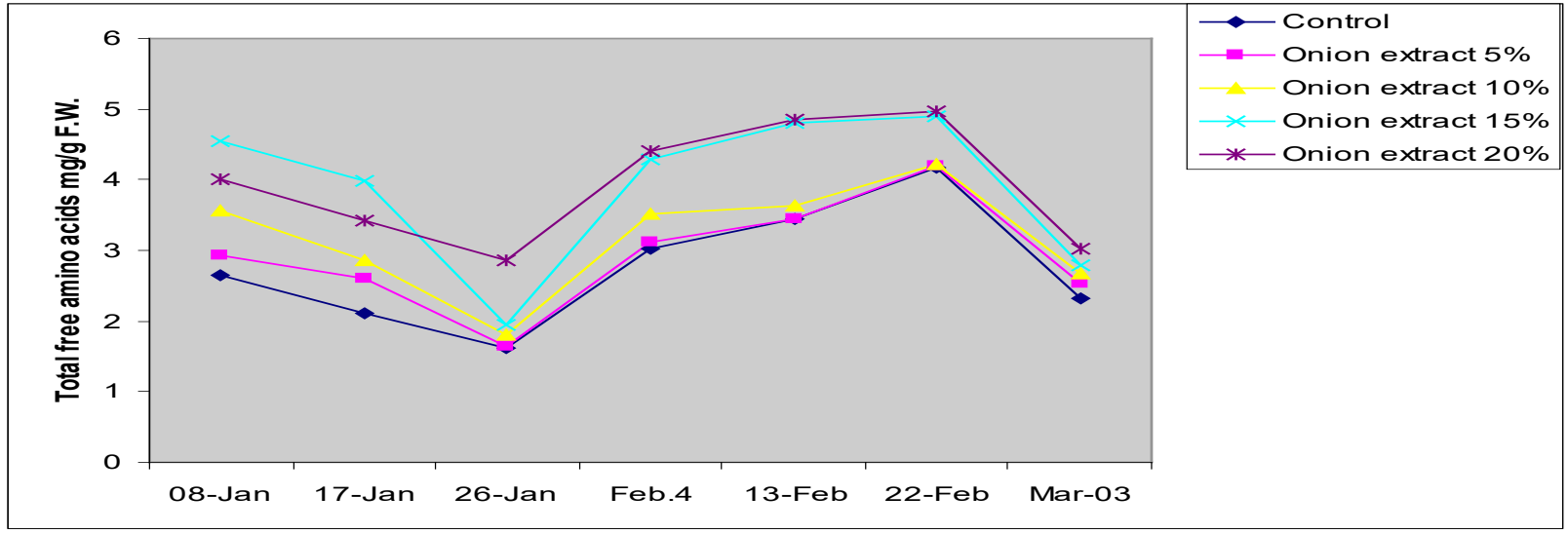

Fig. 6. Effect of foliar spray with different onion extracts on shoot total free amino acids of "Anna" apple trees

\section{Free proline content}

The data in (Fig. 7) indicated that everyone treatments increased the amount of proline in shoots of "Anna" apple variety. The most effective data were obtained by spraying the trees with onion extract at the rate of $20 \%$. The rise was $38.6 \%$ for the sampled date of thirteenth February over the control trees. 


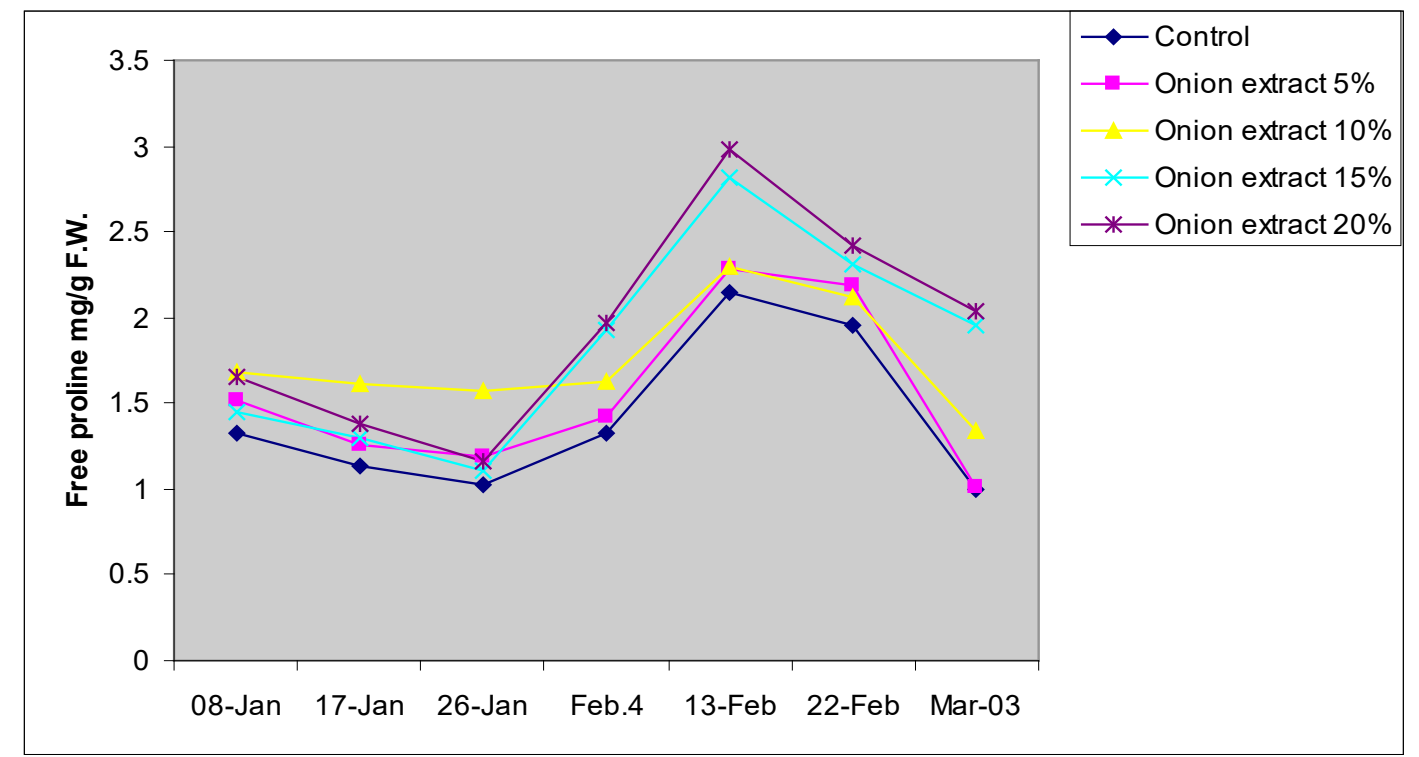

Fig. 7. Effect of foliar spray with different onion extracts on shoot total free proline of "Anna" apple trees

\section{Total indoles content}

Data given in (Fig. 8) usually show that total indoles in "Anna" apple variety step by step attenuated from the primary sample until twenty sixth January, thenceforth it increased step by step reaching its most values at thirteenth February, then attenuated towards the last sample(3th March)
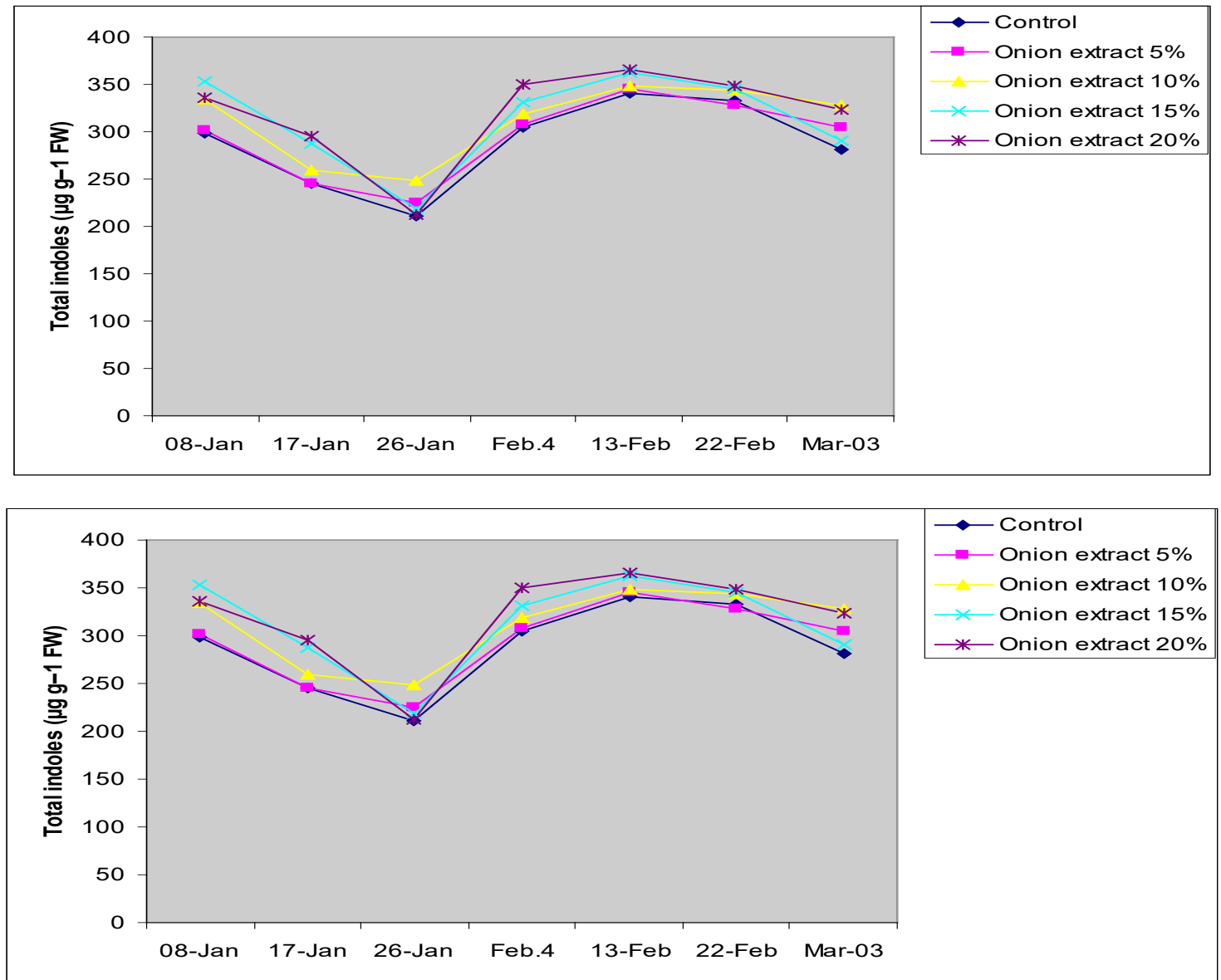

Fig. 8. Effect of foliar spray with different onion extracts on shoot total indoles of

"Anna" apple trees 
The impact of the spray treatments on total indoles, it's clear from the present results that almost all treatments gave higher values of total indoles if compared to the control trees. The most effective data were obtained by spraying the trees by onion extract at the rate of $20 \%$. The rise was $7.6 \%$ for the sampled date of $\left(13^{\text {th }}\right.$ February $)$ over the control trees.

\section{Free phenols content}

The data in (Fig. 9) indicated that the content of free phenols in "Anna" apple variety step by step attenuated from the primary sample reaching its minimum values finally sample (3th March).

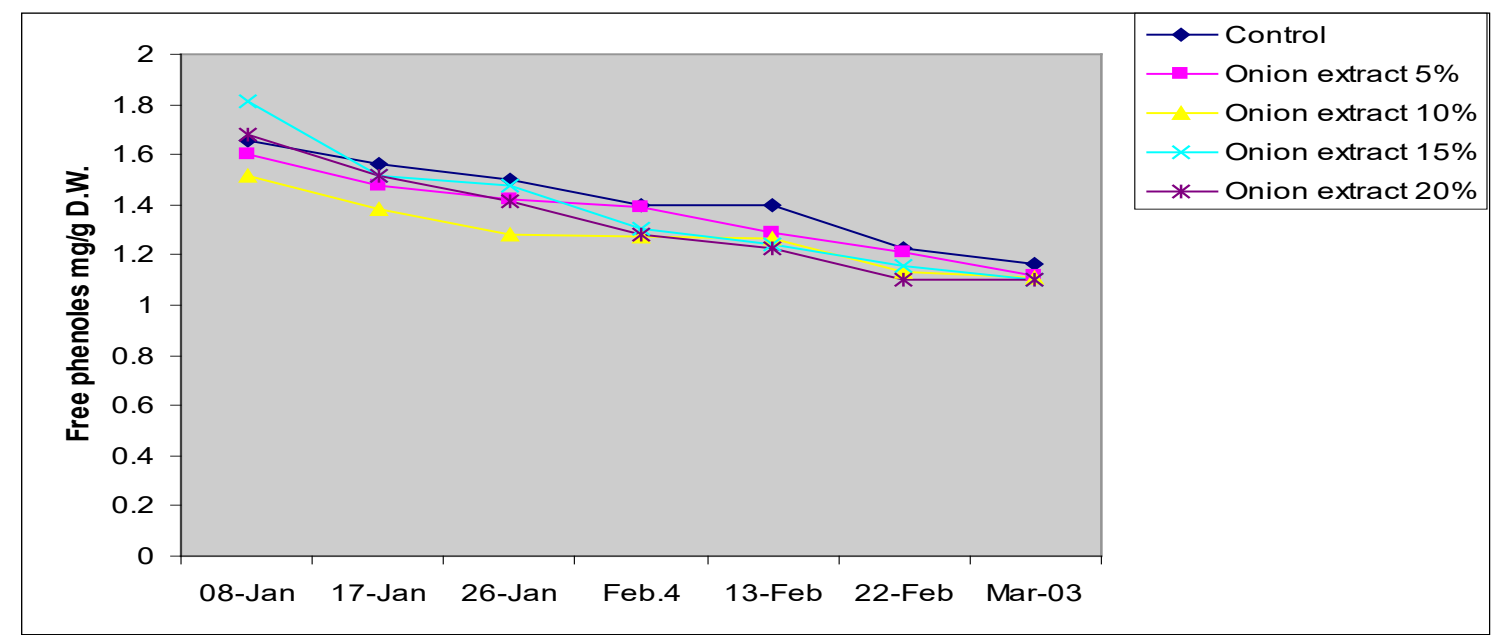

Fig. 9. Effect of foliar spray with different onion extracts on shoot free phenols of "Anna" apple trees

With respect to the impact of the spray treatments on free phenols, it's clear from the present data that just about all treatments gave lowest values of free phenols if comparison to the control trees. The most effective results were obtained by spraying with onion extract at the speed of $20 \%$.

\section{Discussion}

Spraying apple trees with onion extract at five, ten, fifteen and twentieth resulted in vigorous growth any as high productivity with sensible fruit quality for apple trees. Treatments raised the measured growth and flowering estimation this was thanks to the actual fact that these treatments resulted in further convenience of some elements i.e. (sulfur etc.) to trees. During this concern, it's been rumored that exposure to volatiles of diallyl di- and tri-sulfides were the best effective treatment in promoting release bud from dormancy, irrespective of the concentration and therefore the length of exposure [34]. Moreover, the results of dimethyl sulfide compound and diallyl sulfide compound on bud-opining varied among the concentrations and therefore the length of exposure. These results indicate that the active substances liable for bud opining are sulfur-containing substance with an allyl group $\left(\mathrm{CH}_{2} \mathrm{CHCH}_{2}\right)$, significantly diallyl disulfide. During this concern, it was studied the active compounds in onion, this were known as flavonoids, quercetin, myricetin, and kaempferol [35],[36]. Flavonoids, a significant cluster of plant phenols, embrace substance, which are potent antioxidants. The antioxidant activity of flavonols might apparently because of their ability to act as free radical catching [37]. Moreover, phenols cause many multi-biological impactes that ultimately cause the increase in flowering [38]. Also, it had been found that plant phenol was divided into three teams, promotive, inhibitor and inactive compound [39]. It has been further that promotion of plant growth by phenols may proceed through the changes of either IAA biogenesis or its destruction. Promothion of growth and flowering characters with onion extract (as a sulfur natural compound) would be expected since sulfur may will be a constituent of the amino acids cysteine, cystine and methionine and thus proteins. each of those amino acids are precursors of alternative sulfur-containing compounds like secondary plant product and coenzymes. Sulfur could also be structural components of these compounds (e.g., $\mathrm{R}^{1}-\mathrm{C}-\mathrm{S}-\mathrm{C}-\mathrm{R}^{2}$ ) or acts as a useful 
cluster (e.g., R- SH) directly involved in metabolic reactions. General, the active compounds would actuate by an identical mechanism for the dormancy emotional of temperate climate fruit plants, that is, by aerophilous stress throughout the buildup of $\mathrm{H}_{2} \mathrm{O}_{2}$ [40]. In agreement with [40], $\mathrm{H}_{2} \mathrm{O}_{2}$ would operate as a chemical sign activating the expression of genes directly or, indirectly, triggering metabolic alterations which is able to be detected by totally different molecules, as for instance, a kinase, which will activate or repress the expression of genes in command of the dormancy emotional. Throughout this affiliation, it had been discovered that the uses of Allium extract like garlic extracts caused associate aerophilous stress in cells of Candida albicans [41].

The favorable results of the used substances on the date of bud break are additionally thanks to their activation impact of internal gibberellins. Throughout this association, it fully was everywhere that the induction of flowering is also correlative with a natural rise in plant hormone (gibberellin) that promotes flower formation in plants by either facilitating the formation of flowering hormone inside the leaves or expressing it within the growing buds [42]. Also, it fully was rumored that after a bud opens and attains the shape of the shoot, its tip acts as a robust sink for metabolites then being interception center for photosynthates and nutrient result in the earlier begin of the bloom [43]. Moreover, onion extract used during this study, have associate rising result on flowering parameters. This could be attributed to the essential role of these substances within the synthesis of some aminoalkanoic acid and consequently, the formation of growth regulators significantly phytohormone like auxin and ethylene. The simplestive effect of onion extract on yield and its partes was chiefly attributed to its positive action on enhancing growth and flowering parameters. The up result of onion extract on buds water content is additionally due to early activity. Throughout this concern, it completely was suggested that water and nutrients also can also be mobilized to the growing points at the expense of the developing fruits. Moreover, the transition of buds from the dormant stage to the exploding process is expounded to arise at intervals the water content within the tissue, mobilization of nutrients, activation of hydrolytic enzymes and intensification of respiration [45]. The stimulating results of onion extract on total carbohydrates concentrations in buds is additionally directly or indirectly thanks to sure enzymes that activate the anabolic processes leading to the buildup of those substances. Throughout this affiliation, the amount of increase in dry weight of every flower and vegetative buds appear to result to the movement of metabolites may need return from twigs, branches, and roots of trees [46]. The stimulating impact of onion extract on total and reducing sugars is additionally because of that these substances stimulate the conversion of the non-soluble carbohydrates to the soluble ones by activating the hydrolytic enzymes. Throughout this concern, a considerable increase in reducing sugars was evident throughout active growth periods whereas these sugars were really low throughout the amount of retarded growth [47]. Moreover, starch is obtaining used as a supply of metabolites throughout chilling [48]. It's been further collectively that saccharose and hexose (glucose + fructose) are important sugars throughout early growth. Also, varied changes at intervals the extent of carbohydrates occurred in buds as they based from the non-growing stage and start in of growth, they further that starch accumulated throughout the period of photosynthetic activity and is employed for regeneration of growth at intervals the spring [49]. Moreover, reducing sugars induce several multi-biological responses that ultimately cause the promotion of flowering [38]. The rise in total free amino acids in shoots once onion extract treatments might even be thanks to the rise in cysteine, cystine, and methionine since sulfur can be a constituent of these amino acids. Throughout this concern, it had been according that sulfate reduction among the leaves results in export within the phloem of reduced sulfur compounds, principally as glutathione to sites of demand for protein synthesis (e.g., among the shoot apex, fruits, but jointly roots) [50]. Also, nitrogen (including amino acid) was recorded low level in buds or roots throughout the dormant stage and reached most easily before bud break, the nitrogen hold on for the most part inside the roots and trans located to buds before bud break and early growth [51]. Moreover, it had been discovered that a probable correlation could exist between the state of dormancy and additionally the dominant total amino acids inside the buds [46]. 
Moreover, it is been additional that necessary decrease among the dormant standing of buds occurred and this was associated by an raised level of catabolic metabolism of protein [46]. Additional changes to anabolic metabolism nearly fortnigh before bud burst resulted during a very net synthesis of cellular constituents in preparation for bud burst. The decrease in free phenols once onion extract treatments might even be thanks to the reduction in free phenols contrasted with the rise in total indoles i.e. endogenous promoters multiplied and consequently endogenous inhibitors minimized within the shoots which led to increases in plant growth parameters. Throughout this respect, the phenolic impact on plant growth was contributed to either antagonism with IAA activity [52]. Moreover, dormant buds contained a high amount of phenoplast substances that diminished once bud break then multiplied till the beginning of bud enlargement [53]. Phenoplast compounds are found to be patent modifiers of enzyme, catalase, peroxidase, and polyphenol oxidase activity, as every inhibitors and stimulators in apple buds. Moreover, these substances also stimulating the oxidation process of phenols by increasing the peroxidase activity. The stimulating impact of onion extract as a foliar spray on indole acetic acid (IAA) is additionally attributed to the rise in total free amino acids in shoots particularly tryptophan amino acid.

\section{Conclusion}

In view of the aforementioned results, as a substitution of harmful artificial growth regulators, it's been concluded that the results of this study provide proof to the role of onion extract mutually of the natural and safety substances in breaking bud dormancy. Therefore victimization onion extract greatly multiplied flowering and yield still as improved chemical constituents. The constituents of the used substances participate within the utterly totally different metabolic processes that multiplied syntheses of carbohydrates, sugars, anthocyanin, total free amino acids, proline and total indoles that the employment of onion extract could increase apple productivity with high fruit quality. The most effective results were obtained with onion extract number (5) followed by number (4). It might be counseled to use onion extract number (5 or 4$)$ for up bud-break, flowering, yield and chemical constituents of apple shoots.

\section{Acknowledgment}

None.

\section{Conflict of interest}

None.

\section{References}

[1] Arora R, Rowland LJ, Tanino K. Induction and Release of Bud Dormancy in Woody Perennials: a Science Comes of Age. Hort Sci. 2003;38:911-921.

[2] Kumar S, Paul A. Responses to Winter Dormancy, Temperature, and Plant Hormones Share Gene Networks. Funct Integr Genomics. 2011;11:659-664.

[3] Mc Pherson HG, Hall AJ, Stanley CJ. Seasonal and Regional Variation in Bud Break and Flowering of Kiwifruit Vines in New Zeland. J Crop Hortic Sci. 1994;22:263-276.

[4] Heide OM, Prestrud AK. Low Temperature, But Not Photoperiod Controls Growth Cessation and Dormancy Induction and Release in Apple and Pear. Tree Physiol. 2005;25:109-114.

[5] Espinosa-Ruiz A, Saxena S, Schmidt J, Mellerowicz E, Miskolczi P, Bako L, Bhalerao RP. Differential Stage-Specific Regulation of Cyclin-Dependent Kinases During Cambial Dormancy in Hybrid Aspen. Plant J. 2004;38:603-615. 
[6] Bohlenius H, Huang T, Charonnel-Campaa L, Brunner AM, Jansson S, Srauss SH, Nilsson O. CO/FT Regulatory Module Controls Timing of Flowering and Seasonal Growth Cessation in Trees. Science. 2006;31:140-141.

[7] Seif El-Yazal MA, Rady MM. Changes in nitrogen and polyamines during breaking bud dormancy in "Anna" apple trees with foliar application some compounds. Sci Hortic. 2012;136:75-80.

[8] Leonel S, Tecchio MA, Gilli Cóser GM. Dormancy breaking of the fig tree with hydrogen cyanamide and garlic extract. British J Appl Sci Technol. 2015;10(1):1-10.

[9] İmrak B, Küden AB, Küden A, Sarıer K, Çimen B. Chemical application affected dormancy breaking in "Modi" apple cultivar under subtropical conditions. Acta Sci Pol Hort Cult. 2016;15(6):265-277.

[10]Mohamed AA, Gouda FE. Effect of dormex, fructose and methionine spraying on bud dormancy release of "Superior" grapevines. Assiut J Agric Sci. 2017;48(2):75-87.

[11] Seif El-Yazal MA, Rady MM. Exogenous Onion Extract Hastens Bud Break, Positively Alters Enzyme Activity, Hormone, Amino Acids and Phenol Contents, and Improves Fruit Quality in 'Anna' Apple Trees. Sci Hortic. 2014;169:154-160.

[12] Seif El-Yazal MA, Rady MM, Seif El-Yazal SA. Metabolic Changes in Polyamines, Phenylethylamine, and Arginine During Bud Break in Apple Flower Buds Under FoliarApplied Dormancy-Breaking. Intl J Empir Edu Res. 2018a ;1(2):1-18.

[13] Seif El-Yazal MA, Rady MM, Seif El-Yazal SA. Foliar-Applied Mineral Oil Enhanced Hormones and Phenols Content and Hastened Breaking Bud Dormancy in "Astrachan" Apple Trees. Intl J Empir Edu Res. 2018b;1(2):57-73.

[14] Seif El-Yazal MA, Seif El-Yazal SA, Rady MM. Changes in Promoter and Inhibitor Substances during Dormancy Release in Apple Buds under Foliar-Applied Dormancy-Breaking Agents. Intl J Empir Edu Res. 2018c;1(4):1-20.

[15]Morsi ME, El-Yazal MA. Effect of Garlic and Onion Extract on Bud Break, Growth, Yield, Berry Quality and Some Chemical Constituents of "Flam Seedless" and "Superior" Grapevines (Vitis vinifera L.). Egypt J. Hort. 2008a;35:1-28.

[16]Morsi ME, El-Yazal MA. Effect of Potassium Nitrate, Garlic and Onion Extracts on Bud Break, Growth, Yield and Some Chemical Constituents of Apple (Malus sylvestris, Mill) Trees. Fayoum J Agric Res Dev. 2008b;22:82-93.

[17]Rady MM, Seif El-Yazal MA. Response of "Anna" apple dormant buds and carbohydrate metabolism during floral bud break to onion extract. Sci Hortic. 2013;155:78-84.

[18]Abd El-Rzek E, Abd El-Migeed MM, Abdel-Hamid N. Effect of Spraying Garlic Extract and Olive Oil on Flowering Behavior, Yield and Fruit Quality of 'Canino' Apricot Trees. AmerEurasian J Agric Environ Sci. 2011;11:776-781.

[19]Abd El Moniem EA, Abd-Allah ASE. Effect of Green Alga Cells Extract as Foliar Spray on Vegetative Growth, Yield and Berries Quality of Superior Grapevines. Amer-Eurasian J Agric Environ Sci. 2008;4:427-433.

[20]Botelho RV, Pires EJP, Moura MFT, Terra MM, Tecchio MA. Garlic Extract Improves Budbreak of the "Niagara" Grapevines on Sub-Tropical Regions. Ciencia Rural, Santa Maria. 2010;40:2282-2287.

[21]Biasia LA, LIpski B, Silva ED, Oliveira OR, Sachi AT, Peressuti RA. Lime Sulphur Mineral Oil and Garlic Extract to Suppress Dormancy of Kiwi. Revista de Ciencias Agroveterinarias. 2010;9:58-65. 
[22]Rady MM, Seif El-Yazal MA. Garlic Extract as a Novel Strategy to Hasten Dormancy Release in Buds of 'Anna' Apple Trees. S Afr J Bot. 2014;92:105-111.

[23] Seif El-Yazal MA, Rady MM, Seif El-Yazal SA, Morsi ME. Changes in Metabolic Processes during Break Dormancy in Apple Buds under Foliar-Applied Garlic Extract. Intl J Empir Edu Res. 2018d;1(4):36-58.

[24]Rao P, Pattabiraman TN. Reevaluation of The Phenol-sulfuric Acid Reaction for The Estimation of Hexoses and Pentoses. Anal Biochem. 1989;181:18-22.

[25] AOAC. Official Methods of Analysis of the Association of Official Agricultural Chemists. $16^{\text {th }}$ ed., Washington D.C., USA. 1995.

[26] Mancinelli AL. Photoregulation of Anthocyanin Synthesis. VIII. Effects of Light Pretreatments. Plant Physiol. 1984;75:447-453.

[27] Jayarman J. Laboratory Manual in Biochemistry, Wiley Eastern Limited New York, 1981;pp. 61-73.

[28] Chen L, Chen Q, Zhang Z, Wana X. A novel Colorimetric Determination of Free Amino Acids Content in Tea Infusions with 2,4-Dinitrofluorobenzene. J Food Composit Anal. 2009;22:137141.

[29]Ennajeh M, Vadel AM, Khemira H, Ben Mimoun M, Hellali R. Defense Mechanisms Against Water Deficit in Two Olive (Olea europaea L.) Cultivars 'Meski' and 'Chemlali'. J Hortic Sci Biotechnol. 2006;81:99-104.

[30] Snellings SL, Takenaka NE, Kim-Hayes Y, Miller DW. Rapid Colorimetric Method to Detect Indole in Shrimp with Gas Chromatography-Mass Spectrometry Confirmation. J Food Sci. 2003;68:1548-1553.

[31] Snell FD, Snell CT. Azo Compounds, Nitrogen-Containing Cycles, and So On In: Snell FD, Snell CT, authors. Colorimetric Methods of Analysis Including Photometric Methods. Princeton: D Van Nostrand Co Inc, 1967;pp 448-601.

[32] Galicia L, Nurit E, Rosales A, Palacios-Rojas A. Laboratory Protocols: Maize Nutrition Quality and Plant Tissue Analysis Laboratory. Mexico, DF: CIMMYT. 2009.

[33] Gomez KA, Gomez AA. Statistical Analysis Procedure of Agricultural Research. John Wiley and Sons, New York, 1984;pp. 25-30.

[34] Kubota N, Yamane Y, Toriu K, Kawazu K, Higuchi T, Nishimura S. Identification of Active Substances in Garlic Responsible for Breaking Bud Dormancy in Grapevines. J Japan Soc Hortic Sci. 1999;68(6):1111-1117.

[35]Crozier A, Mc Donald MS, Black C. Quantitative Analysis of the Flavonoid Content of Commercial Tomatoes, Onions, Lettuce and Celery. J Agric Food Chem. 1997;45:590-595.

[36] Sellappan S, Akoh CC. Flavonoids and Antioxidant Capacity of Georgia- Grown Vidalia Onions. J Agric Food Chem. 2002;50:5338-5342.

[37]Xiao H, Parkin KL. Antioxidant Function of Selected Allium Thiosulfinates and S-alkyl-LCysteine Sulfoxides. J Agric Food Chem. 2002;50:2488-2493.

[38]El-Mansy HI, Walker DR. Seasonal Fluctuation in Elberta Peach Flower Bud During and After the Termination of Rest. J Amer Soc Hortic Sci. 1969;94:298.

[39]Kefeli V, Kutacek M. Phenolic Substances and Their Possible Role in Plant Growth Regulation. Plant Growth Regul. 1977;5:472. 
[40]Pinto M, Lira V, Ugalde H, Perez F. Fisiologia de la Latencia de Las Yemas de vid: Hipótesis actuales. Santiago: Universidad de Chile. 2008; p.16. Available

from:http://agronomia.uchile.cl/extension/serviciosyproductos/gie/publicaciones. Accessed: Dec 24, 2007

[41]Lemar KM, Passa O, Aon MA, Cortassa S, Müller CT, Plummer S, O'Rourke B, Lloyd D. Allyl Alcohol and Garlic (Allium sativum) Extract Produces Oxidative in Candida albicans. Microbiology, Reading, 2005;151:3257-3265. Available from: $<$ http://mic.sgmjournals.org/cgi/reprint/151/10/ 3257>. Accessed: Dec 20, 2009. doi: 10.1099/mic.0.28095-0.

[42] Subha-drabandhu S. Induction of Bud Break in Apple Trees that Received Insufficient Chilling by Hydrogen Cyanamide. Acta Hortic. 1995;409:171-178.

[43] Skene KGM. A comparison of The Effects of Cycocell and Tipping on Fruit Set Vitis vinifera L. Aust J Bio Sci. 1969;22:1305-1311.

[44]George AP, Nissen RJ, Lioyed J, Richens K. Factors Affecting Fruit Quality of Low Chill Stone Fruit in Subtropical Australia. Acta Hortic. 1990;279:559-564.

[45]Borkowska B. Releasing the Single Apple Buds from Dormancy Under the Influence of Low Temperature, BA and ABA. Fruit Sci Rep. 1980;7:174-183.

[46]Bachelard EP, Wightman F. Biochemical and Physiological Studies on Dormancy Release in Tree Buds. Can J Bot. 1973;51:2315-2326.

[47]Baz AGIO. Some Physiological Studies on Dormancy in Mit- Ghamr Peach Cultivar. Aseasonal Changes in Native Growth Materials Related to Bud Dormancy in Peach. Ann Agric Sci, Moshtohor, Egypt. 1984;21:465-479.

[48] Young E. Cytokinin and Soluble Carbohydrates Concentrations in Xylem Sap of Apple During Dormancy and Bud Break. J Amer Soc Hortic Sci. 1989;114:297-300.

[49] Gemma H. Dormancy Breaking in Japanese Pears Grown in A heated Greenhouse. Acta Hortic. 1995;395:57-67.

[50]Rennenberg H. Synthesis and Emission of Hydrogen sulfide by Higher Plants. In 'Biogenic Sulfur in the Environment " (E.S. Saltzman and W.J. Cooper, eds.), 1989;pp. 44-57. ACS Symp. Series 3296, Washington, DC.

[51] Kuroi I. Studies on The Promotion of Grape Vines by The Lime Nitrogen Treatment During The Rest Period. Memoirs Fac Agric, Niigata Univ. 1974;12:1-17.

[52] Sagi F, Garay AS. The Dependence of Auction Oxidase Activity on The Photoperiodically Conditioned Phenol Content of The Leaves and Their Age in Lupinus albus. Hortic Abs. 1961;31:3688.

[53] Wang SF, Clark CJ, Boldingh HL. Changes in The Activities of Catalase, Peroxidase and Polyphenol Oxidase in Apple Buds During Bud Break Induced by Thidiazurin. J Plant Growth Regul. 1991;10:3-39. 